\title{
The Impact of International Direct Investment on Chinese Economy
}

\author{
Yingdong Chen ${ }^{1}$ Xiaocheng Sun ${ }^{1, *}$
}

\author{
${ }^{1}$ School of Management, Dalian polytechnic University, Dalian, Liaoning116034, China \\ *Corresponding author. Email: 52208890@qq.com
}

\begin{abstract}
In recent years, with the rapid development of economic globalization, the rapid growth of China's economy, because of its vast territory and abundant resources, China has now become the country with the largest accumulated foreign investment, and its number is still rising rapidly. Foreign direct investment has made great contributions to the inflow countries, mainly through the introduction of cutting-edge global technology to achieve top-level information. At the same time, it also shows China a more rational and efficient management model, and increases employment and employment rate to solve most of the unemployment problems. Foreign investment in China has not only increased China's economic capacity, but also introduced a lot of high-tech and new technologies, provided a lot of jobs, and solved the employment problem of most people. The government should not only create a good environment for foreign investment from the aspects of economy, life and culture, but also from the aspects of infrastructure construction, market economy system environment, rules and regulations and human resources. Improving the absorptive capacity of FDI will be one of the most important tasks in China's economy. This paper discusses the positive and negative effects of international direct investment on China's economy.

Keywords: international direct investment, economic growth, Chinese economy
\end{abstract}

\section{INTRODUCTION}

Nowadays, the development of the world economy has evolved into a global division of labor and cooperation. Among them, the maximum probability of foreign investment in China. FDI has made great contributions to the inflow countries, mainly through the introduction of cutting-edge global technology to achieve top-level information, but also to show China a more rational and efficient management model. Introduce some foreign experience and equipment such as perfect management system, scientific means and industrial capacity[1]. It not only improves the competitiveness of the market, but also introduces a lot of high-tech information energy. For developing countries, there are some restrictive factors such as relative lack of financial resources and relatively backward technology, so foreign investment is an important issue for China's market economy[2]. The prosperity and development of China's economy cannot be separated from the introduction of foreign direct investment. The economic dawn brought by reform and opening up confirms this view. It has created a good environment for foreign investment in terms of infrastructure construction, market economy system environment, rules and regulations and human resources.

\section{The Relationship Between Foreign Direct Investment and China's Economic Growth}

In the 1990s, Singapore's GDP exceeded $\$ 50$ billion for the first time, but it invested $\$ 20$ billion in Suzhou Industrial Park[3]. Singapore's investment in Suzhou is also a coincidence. Qingdao, Hangzhou and other big cities compete together. Not only culture, history and scale are similar, but the economy of cities is not so different[4]. Finally, it chose Suzhou. There are many reasons. Among them was the mayor of Suzhou at that time, who spoke fluent English, which also made the Golden Rooster lake of Suzhou Industrial Park.

The relationship between China's rapid economic development and the introduction of foreign direct investment has not only attracted the attention of domestic economists, but also scholars agree that foreign direct investment has greatly promoted the growth of China's GDP and stock. Most of the foreign direct investment we have introduced is in processing trade. More importantly, most of the technological property rights of the export goods of processing trade are controlled In the hands of multinational companies in developed countries[5]. And it is basically in the monopoly link, so the profits brought by commodity export will eventually return to the developed countries to a large extent. To some extent, the impact on China's economic take-off should be very limited[6]. In terms of competitiveness, most scholars provide data and 
analysis, recognizing that international direct investment has promoted China's export rate and import rate, but also improved the technical competitiveness of the industry. The inflow of foreign direct investment will enable enterprises to learn from the advanced production process and technology management mode of transnational corporations. For China's national conditions, science and technology are also developing on tablecloth[7]. At present, foreign trade is mainly limited to the export of primary products and simple reprocessed products. But we must see that with the introduction of foreign direct investment, China's various capabilities have been mature, technology has been over fulfilled, the composition and optimization of the industrial chain, the steady flow of capital, and the level of talent training has been increasing. Primary products and simple reprocessed products are not the only means for China[8]. China's export products have developed rapidly in terms of technology level and industrial chain, as well as technology level. With the increase of foreign investment and the continuous adjustment of industrial structure, the export structure of products is becoming more and more reasonable, and the export competitiveness is also correspondingly improved. In general, FDI has made up for the shortage of investment in China. It not only obtains advanced technology from developed countries, but also absorbs advanced management experience from developed countries. It has also increased employment and employment rates in developing countries. From talent training to talent management, we have accumulated valuable capital in all aspects of quality improvement. More importantly, the introduction of international direct investment has brought advanced technology and management experience as well as international market and competitiveness, making China increasingly have an international vision and participate in international information and technology competition[9]. In terms of total foreign direct investment and growth rate, China has become the country with the highest return on foreign investment. Foreign investment has continued to develop rapidly in both quantity and growth rate. The inflow of international direct investment has been increasing, the structure has been optimized, and the field has been expanding. In 2009-2010, 10 countries have been rated as the most popular investors by multinational companies, and have shown great enthusiasm for investment. They are China, India, Vietnam and Indonesia in Asia, America, Brazil, Russia, Australia and Canada, etc. Under the strong guidance of the Chinese government, China's economy continues to develop rapidly, its economic theory is rapidly improved, a large number of economic talents are trained, domestic demand is expanding, China still has a very rich labor force, and the international market is expanding. The overall strength is growing rapidly. The role of foreign capital in China's economic development will become a hot issue[10].

\section{THE NEGATIVE IMPACT OF INTERNATIONAL DIRECT INVESTMENT ON CHINA'S ECONOMY}

Thirty two years of reform and opening up have brought remarkable achievements. China's rapid economic development has made it a world leader. It is hailed as a miracle of world economic development. International direct investment is a mysterious force. Under the policy of reform and opening up, China's economic development has not only improved its economic market, but also introduced relevant laws and regulations. On March 15, 2019, the second session of the 13th National People's Congress passed the law of the people's Republic of China (hereinafter referred to as foreign investment law, Foreign Investment Law), which came into force on January 1, 2002. The legal text of the general investment law provides standardized macro guidance on foreign investment, investment promotion, investment management, investment and responsibility, so as to promote foreign investment, foreign investment and protect the legitimate rights and interests, and standardize the socialist construction in the new stage of foreign investment management, forming an open and new pattern[11].

There is an old saying "if we establish good laws in the world, then the world will be governed; if we establish good laws in one country, then one country will be governed." Under the strategic guidance of the 19th National Congress of the Communist Party of China, "greatly relax market access, expand the opening up of the service industry, and protect the legitimate rights and interests of foreign investment", the foreign investment law takes into account the new situation at home and abroad, and specifically solves the new contradictions in the process of investment and opening up, which not only demonstrates the great legal exploration of socialism with Chinese characteristics in the new era, but also provides a new model for global foreign investment governance The establishment of the model contributes to the outstanding Chinese wisdom.

However, China is the target of FDI, and has been plagued by the introduction of monopoly and targeting of emerging competitors. In the Chinese market, the behavior of multinational companies is still based on their own interests to maximize the deployment of economic investment[12]. Foreign direct investment is becoming more and more obvious in China's economic development. In academic discussions, foreign direct investment has a negative impact on China's economy.The most obvious example is POS.

More importantly, foreign direct investment is the biggest threat to China's economy. In 2008, the global financial crisis brought a background to the world[13]. The study of foreign direct investment has affected the economy of part of China's industries. Once foreign direct investment enterprises are affected by the financial crisis, they will become very passive and have no initiative. At the same time, the rise of private economy has also changed the relevant driving structure. 
How to strengthen the competitiveness of China's local private enterprises, improve the quality and competitiveness of products is also our problem. Since 1978, with the economic, cultural and economic development of the country, the state-owned enterprises have made greater efforts to carry out reform, improving the efficiency and competitiveness of the state-owned enterprises, opening up to the outside world, introducing advanced technology, enhancing management capacity and increasing capital investment. Since the reform and opening up, foreign direct investment has been an important part of the national economy[14]. In 1994, China's foreign direct investment began to grow. In 2002, the total amount of foreign direct investment in China reached 50 billion US dollars, which will surpass the United States and become the largest foreign direct investment in the world. The policy of reform and opening-up in China has solved the capital bottleneck of modern development in China. Foreign advanced technology and management experience have made great progress in China's productivity.

On the other hand, the dependence of China's economy on foreign direct investment and the industrial structure of China's direct investment have become the world manufacturing center.

According to Ricardo's basic theory, the basis of international division of production is the inspection of resources owned by a country. From the perspective of abundant labor resources, low price, environment and external resources, low cost and large-scale investment, statistics show that the investment of multinational companies in China is mainly concentrated in the secondary industry, that is, the traditional industries with high energy consumption, pollution and low value-added products, which have driven the development of many developed countries and multinational companies. The theory of promoting truss power supply in our country provides a revelation that can not be ignored. Environmental problems are increasingly prominent, water pollution and leakage of toxic and harmful substances occur from time to time.

Faced with severe social problems, employment and environmental patterns, China's economic transformation is imminent. Sustainable development is a new way of economic development in China. As a whole, the society needs to develop harmoniously, solve a problem, and invest in places where there will be no problem. For the development of foreign economy in China, with so many choices of national policies for economic development and transformation, it is necessary to analyze the economic impact of foreign direct investment on the host country.

We hope to find a model and a suitable way to make use of the advantages of finance, technology and foreign direct investment. For our country, it will play a huge role in the sustainable development of the transitional economy.

\section{SUMMARY}

In China, the main target of international direct investment is the developing countries with low human cost and the investment of western developed countries. East Asian countries or regions are the main ones, supplemented by European and American countries. The impact of international direct investment on China's economy is as follows:

First, we will strengthen the impact of foreign direct investment on China and gradually eliminate preferential terms and policies for foreign enterprises. In the early stage of reform and opening up, due to the limitations and obstacles of economic development and ideology, the policy of international direct investment was correct in macro sense, and promoted the development of China's economy. Traditional policies of attracting FDI and preferential policies are becoming less and less advantageous. On the contrary, China's economic development is normal, with obstacles and limitations to progress. Therefore, it is necessary to eliminate foreign investment that generally enjoys preferential policies for enterprises with foreign investment. In some industries, some regions or some types of projects, it is still necessary to maintain some good overall development strategies and industrial policies that are closest to the direction of foreign direct investment.

Second, improve market competitiveness. Blind and unrestrained introduction of foreign investment will bring about negative effects that cannot be ignored. This idea of neglecting the development of domestic capital will lead to the development of domestic capital in a difficult period, or even the stagnation of development, which will be replaced by foreign capital, and finally fall into disintegration or collapse. Therefore, it provides opportunities for domestic investment to learn advanced technology and ideas. In addition, according to the actual situation of our country, and using the laws and regulations, we can reduce the harm of multinational companies to our enterprises and people in the loopholes of laws, and also reduce a series of problems related to tax evasion and tax evasion.

Last, pay attention to talent education and cultivate innovative talents to a large extent, the level of human resources in FDI is still a key decision-making position and an irreplaceable key issue. Only by adhering to the principle of people-oriented and giving full play to the advantages of talents, can we learn advanced technology and management from foreign enterprises to become our own culture and internal circulation in every blood and cell in our body. We will take advanced technology and management concepts into consideration of domestic enterprises. Only by absorbing foreign direct investment, improving the comprehensive quality of our employees and learning relevant management skills and forming a set of our own system can China's foreign direct investment really play a role. 
[10] Jacek Pietrucha. TFP spillover effects via trade and FDI channels[J]. Ekonomska Istraživanja,2019.

[11] Pablo Ponce,Rafael Alvarado. Air pollution, output, FDI, trade openness, and urbanization: evidence using DOLS and PDOLS cointegration techniques and causality[J]. Environmental Science and Pollution Research,2019,26(19).

[2] Waqih Muhammad Abaid Ullah,Bhutto Niaz Ahmed,Ghumro Niaz Hussain,Kumar Suresh,Salam Muhammad Abdul. Rising environmental degradation and impact of foreign direct investment: An empirical evidence from SAARC region.[J]. Journal of environmental management,2019,243.

[3] Uzar Umut,Eyuboglu Kemal. Is foreign direct investment an engine for energy consumption? An empirical investigation for Turkey.[J]. Environmental science and pollution research international,2019,26(27).

[4] Zhang Jie,Qu Yinxiao,Zhang Yun,Li Xiuzhen,Miao Xiao. Effects of FDI on the Efficiency of Government Expenditure on Environmental Protection Under Fiscal Decentralization: A Spatial Econometric Analysis for China.[J]. International journal of environmental research and public health,2019,16(14).

[5] Faheem Ur Rehman,Muhammad Asif Khan,Muhammad Atif Khan,Khansa Pervaiz,Idrees Liaqat. The causal, linear and nonlinear nexus between sectoral FDI and infrastructure in Pakistan: Using a new global infrastructure index[J]. Research in International Business and Finance,2020,52.

[6] Hyungkee Young Baek,Pankaj K. Maskara,Laura S. Miller. Does Improved Governance Lead to a Higher Share of FDI in Foreign Equity Investments?[J]. Asia Pacific Journal of Financial Studies,2019,48(4).

[7] ADA FDI World Dental Congress 2019 concurrent meetings[J]. Elsevier,2019,150(8).

[8] Zhang Jie,Qu Yinxiao,Zhang Yun,Li Xiuzhen,Miao Xiao. Effects of FDI on the Efficiency of Government Expenditure on Environmental Protection Under Fiscal Decentralization: A Spatial Econometric Analysis for China.[J]. International journal of environmental research and public health,2019,16(14).

[9] Gorynia,Nowak,Trąpczynski,Wolniak. Geographic patterns of Poland' s FDI: the investment development path perspective[J]. Post-Communist Economies,2019,31(4).
[12] Erik Hille,Muhammad Shahbaz,Imad Moosa. The impact of FDI on regional air pollution in the Republic of Korea: A way ahead to achieve the green growth strategy?[J]. Energy Economics,2019,81.

[13] Philip Kofi Adom,Eric Evans Osei Opoku,Isabel Kit-Ming Yan. Energy demand - FDI nexus in Africa: Do FDIs induce dichotomous paths?[J]. Energy Economics,2019,81.

[14] Lin Cui, Ying Xu. Outward FDI and profitability of emerging economy firms: Diversifying from home resource dependence in early stage internationalization[J]. Journal of World Business, 2019,54(4). 